\title{
Performance, sizing and total solids of nine onion (Allium cepa) cultivars'
}

\author{
Elvin Carabllo, Guillermo J. Fornaris," Rubén Guadalupe" \\ and Evangelina Recio de Hernández"
}

\begin{abstract}
Onion cultivars Granex 33, Granex 429, Texas Grano 502, Texas Grano 1025 Y, Texas Grano 1105 Y, FMX-225, Texas Grano 1030 Y, Texas Early Grano 502 and Texas Grano $1015 Y$ were evaluated at the Fortuna Agricultural Experiment Substation in Juana Díaz, P. R. from late November 1985 to early April 1986. Granex 33 and Granex 429 gave highest marketable yields: 33,075 and $32,194 \mathrm{~kg} / \mathrm{ha}$, respectively. These yields were significantly higher than yields of other cultivars except Texas Grano 502. These cultivars were also the best in terms of size classification. There were no significant differences in average bulb weight among most of the cultivars. Granex 33 had the highest density and Texas Grano $1030 \mathrm{Y}$ had the highest percentage of total solids.
\end{abstract}

\section{RESUMEN}

Producción, tamaño y porcentaje de sólidos totales de nueve variedades de cebolla (Allium cepa)

Se evaluaron las variedades de cebolla Granex 33, Granex 429, Texas Grano 502, Texas Grano 1025 Y, Texas Grano 1105 Y, FMX-225, Texas Grano 1030 Y, Texas Early Grano 502 y Texas Grano 1015 Y en la subestación de Fortuna en Juana Díaz, P. R. desde fines de noviembre de 1985 hasta principios de abril de 1986. Los rendimientos de las cultivares Granex 33 y Granex 429 fueron significativamente mayores $(33,075$ y 32,194 kg./ha.) que los de las otras variedades, excepto Texas Grano 502. Estas tres variedades produjeron bulbos de mejor tamaño y aceptables comercialmente. No hubo diferencia entre variedades en cuanto al peso medio del bulbo. Los bulbos de las variedades Granex 33 y Texas Grano 1030 Y fueron los de mayor densidad y mayor porcentaje de sólidos totales.

\section{INTRODUCTION}

In 1986, Puerto Rico imported $\$ 157$ million worth of fresh and processed vegetables from the United States and $\$ 20$ million from other countries. The Vegetable Program on the south coast of Puerto Rico produced $\$ 21$ million worth of vegetable crops. Thus, the deficit in the vegetable industry was approximately $\$ 156$ million $(1,4)$.

Onions are an important item of consumtion in Puerto Rico. Annual per capita consumption of onions increased from $4.08 \mathrm{~kg}$ in $1974-75$ to

'Manuscript submitted to Editorial Board 26 January 1989.

"Research Assistant, Department of Horticulture.

${ }^{3}$ Horticulturist. Department of Horticulture.

'Assistant Food Technologist, Food Technology Laboratory. 
$5.75 \mathrm{~kg}$ in $1985-86$. In $1985-86$ the 40.65 ha planted to onions produced 1,015 metric tons (4). The same year, 18,882 metric tons were imported to supply the local demand.

Expansion of commercial onion production requires high yielding, good quality, well-adapted, short-day onion cultivars (6). This requirement demands continuous testing for performance and product quality of promising commercial cultivars available mainly from seed companies in the United States.

This paper presents the results of a trial conducted to evaluate the performance, size and total solids of a group of onion (hybrids and open pollinated) cultivars.

\section{MATERIALS AND METHODS}

The study herein reported was conducted at the Fortuna agricultural experiment substation in Juana Díaz, on the south coast of Puerto Rico. The soil is classified as a San Antón clay loam, a Mollisol (Cumulic Haplustolls, fine-loamy, mixed, isohyperthemic) with $\mathrm{pH}$ 7.9. Rainfall and temperature data were recorded during the growing season.

Table 1 gives information on the characteristics and sources of the cultivars tested. They were all yellow or straw yellow, which is the color preferred by local consumers. According to seed sources, days to matur-

TABLE 1.-Characteristics and source of the onion, cultivars included in the 1985-86 variety trial at the Fortuna agricultural experiment substation'

\begin{tabular}{|c|c|c|c|c|}
\hline Cultivar ${ }^{2}$ & Source & $\begin{array}{l}\text { Relative days } \\
\text { to maturity }\end{array}$ & Type: & Color \\
\hline Granex $33^{s}$ & Asgrow & 162 & $F_{1}$ & Yellow \\
\hline Granex 419 & Asgrow & 165 & $F_{l}$ & Yellow \\
\hline Texas Grano $502^{4}$ & Asgrow & 168 & O.P. & Straw \\
\hline Texas Grano $1025 \mathrm{Y}^{\mathrm{Y}}$ & Asgrow & 182 & O.P. & Straw Yellow \\
\hline Texas Grano $1105 \mathrm{Y}$ & Dr. L. M. Pike & & & \\
\hline & Texas A\&M Univ. & 180 & O.P. & Yellow \\
\hline FMX - 225 & Ferry Morse & 170 & $F_{1}$ & Straw Yellow \\
\hline Texas Grano $1030 \mathrm{Y}$ & Dr. C. M. Pike & & & \\
\hline Texas Early & Texas A\&M Univ. & 180 & O.P. & Yellow \\
\hline $\begin{array}{l}\text { Grano } 502 \\
\text { Texas Grano }\end{array}$ & Ferry Mlorse & 170 & O.P. & Straw \\
\hline $1015 \mathrm{Y}$ & Asgrow & 168 & O.P. & Straw Yellow \\
\hline
\end{tabular}

'As described by seed sources.

${ }^{2}$ All cultivars were pink rot resistant.

${ }^{3}$ O.P. = Open pollinated; $F_{1}=$ hybrids .

${ }^{4}$ Control cultivars for comparison purposes. 
ity range from 162 in Granex 33 to 180 in Texas Grano $1105 \mathrm{Y}$ and Texas Grano $1015 \mathrm{Y}$ for an average of 170 . However, this study reveals that a good commercial onion crop can be obtained in southern Puerto Rico in less than 130 days.

Seeds of the nine onion cultivars were sown in the field 21 November 1985, in double-row plots, $366 \mathrm{~cm}$ (12 ft) long with plants spaced $8 \mathrm{~cm}(3$ in) within rows, and at $31 \mathrm{~cm}$ (12 in) between rows. The trial was arranged in a balanced lattice design with four replications.

The experiment was fertilized at a rate of $227.3,227.3$, and 181.8 $\mathrm{kg} / \mathrm{ha}$ ( 200,200 and $160 \mathrm{lb} / \mathrm{acre})$ of $\mathrm{N}, \mathrm{P}_{2} \mathrm{O}_{5}$ and $\mathrm{K}_{2} \mathrm{O}$, respectively. Fifty percent of the total amount of fertilizer was applied before planting; the rest was applied 45 days after planting. Sprinkler irrigation was applied twice a week for the first 2 weeks at the rate of 1 inch, and once a week thereafter up to 30 days before harvest.

Dacthal W-175 was applied immediately after planting at the rate of $15.8 \mathrm{~kg} / \mathrm{ha}$ (14 lb./acre) as a preemergent herbicide. Six weeks later, Fusilade and Goal were applied at the rate of $0.42 \mathrm{~kg}$ ai/ha $(0.37 \mathrm{lb}$ ai/acre) and $0.28 \mathrm{~kg}$ ai/ha (0.25 lb. ai/acre), respectively, as postemergent herbicides.

A preventive weekly spraying program was scheduled to control insects and diseases $(2,3)$. Diazinon AG 500 and Nudrin 90 were applied at the rate of $0.55 \mathrm{~L} \mathrm{ai} / \mathrm{ha}(0.47 \mathrm{pt}$ ai/acre $)$ and $1.7 \mathrm{~kg} \mathrm{ai} / \mathrm{ha}(1.5 \mathrm{lb}$ ai/acre), respectively, to control insects. Dithane $\mathrm{M}-45$ and Ridomil MZ-58 were used at the rate of $1.60 \mathrm{~kg}$ ai $/ \mathrm{ha}(1.4 \mathrm{lb}$ ai/acre $)$ and $0.93 \mathrm{~kg}$ ai $/ \mathrm{ha}(0.82 \mathrm{lb}$ ai/acre), respectively, to control fungi.

Bulbs were harvested when the green tops weakened just above the bulb and fell over $(5,7,8)$. Onions were harvested 17 March, 25 March and 4 April 1986 (table 3). After 10-day curing, bulbs were counted, weighed and classified as to size. Also, total marketable yields were calculated. A sample of 20 dry bulbs per plot was analyzed at the Food Technology Laboratory for total solids, size distribution, volume and density. Onions were classified under USDA bulb size classes, 1 to 19, based upon bulb diameter from 4.75 to 1.00 inch. The Archimides principle (water displacement) was used to determine average bulb density.

\section{RESULTS AND DISCUSSION}

Table 2 presents data on weather conditions during the crop cycle. Total rainfall amounted to $153 \mathrm{~mm}$. Monthly distribution ranged from 2 $\mathrm{mm}$ in December 1985 to $72 \mathrm{~mm}$ in April 1986. Variations in mean average and mean maximum daily temperature were negligible. Mean maximum temperature was $17.6^{\circ} \mathrm{C}$ in February 1986 and rose to 20.4 in April. Climatic conditions apparently favored bulb formation. The increased decay observed towards the end of the growing cycle could be attributed to the April rains. 
TARLE 2-Weather conditions during the 1985-86 crop cycle November 1.985 through April 1986.

\begin{tabular}{llllr}
\hline & \multicolumn{3}{c}{ Average daily temperature (C) } & \\
\cline { 2 - 3 } Month & Max. & Min. & Mean & Rainfall \\
\hline & & & & mm \\
November 1985 & 30.8 & 19.8 & 25.3 & 38 \\
December 1985 & 30.3 & 18.7 & 24.5 & 2 \\
January 1986 & 29.7 & 18.2 & 23.9 & 8 \\
February 1986 & 29.2 & 17.6 & 23.4 & 28 \\
March 1986 & 30.3 & 18.7 & 24.5 & 5 \\
April 1986 & 30.3 & 20.4 & 25.3 & 72 \\
\hline
\end{tabular}

Total marketable yield of cultivars Granex $33(33,075 \mathrm{~kg} / \mathrm{ha})$ and Granex $429(32,194 \mathrm{~kg} / \mathrm{ha})$ was significantly higher $(\mathrm{P}=0.05)$ than that of the other cultivars tested except Texas Grano 502 (table 3). Cultivars Texas Grano 502 and Texas Grano 1025 Y outyielded the remainder in terms of marketable yield. Mean production of these four cultivars was close to $30,000 \mathrm{~kg} / \mathrm{ha}$. The mean production of all other cultivars pooled together was around $20,500 \mathrm{~kg} / \mathrm{ha}$. Texas Grano $1015 \mathrm{Y}(15,525 \mathrm{~kg} / \mathrm{ha})$ yielded lowest. The poor performance of this cultivar was mostly attributable to decay. No significant differences were observed in average bulb weight among most of the cultivars. Furthermore, there were no significant differences in number of bulbs per hectare among most of the cultivars, but Texas Grano 1015 Y produced the fewest bulbs.

The percentage of total solids ranged from 7.59 to 8.67. Texas Grano $1030 \mathrm{Y}$ and Granex 429 showed the highest percentage of total solids, whereas Granex 33 (7.54) and Texas Grano 1105 Y (7.57) showed the lowest.

As to bulb density, there were almost no differences among cultivars, but Granex 33 and Texas Grano 502 had the highest $\left(2.11 \mathrm{~g} / \mathrm{cm}^{3}\right)$, whereas density of Texas Grano 502 was only $2.00 \mathrm{~g} / \mathrm{cm}^{3}$.

Granex 33, Granex 429 and Texas Grano 502 produced the highest percentage of bulbs $7.5 \mathrm{~cm}$ (3) or larger in diameter (table 4). Texas Early Grano 502 and Texas Grano 1015 Y produced more bulbs smaller than $7.5 \mathrm{~cm}(3 \mathrm{in})$. Overall, the diameter of the bulbs of the majority of the cultivars measured 7.0 ( $2.75 \mathrm{in})$ to $8.9 \mathrm{~cm}$ (3.50 in).

In terms of trial marketable yield, cultivars Granex 33 and 429 must be preferred for commercial plantings on the south coast of Puerto Rico. However, there might be other criteria to be considered when recommending a new variety for commercial production. 
TABLE 3.-Perfomnance of nine onion cultivars during the 1985-86 seasant $^{t}$

\begin{tabular}{|c|c|c|c|c|c|c|}
\hline Cultivar: & $\begin{array}{l}\text { Harvest } \\
\text { date }\end{array}$ & $\begin{array}{l}\text { Total marketable } \\
\text { jield }\end{array}$ & $\begin{array}{l}\text { Total no. of } \\
\text { bulbs per ha }\end{array}$ & $\begin{array}{l}\text { Average } \\
\text { weight }\end{array}$ & $\begin{array}{l}\text { Total } \\
\text { solids }\end{array}$ & Density \\
\hline & & kg/ha & & $g^{\prime} l \mathrm{lulb}$ & $\%$ & $g^{\prime} \mathrm{cm} h^{x}$ \\
\hline Granex 33 & $3-17-86$ & $33,075 \mathrm{a}^{2}$ & $250,221 \mathrm{a}$ & $132 a$ & 7.54 & 2.11 \\
\hline Granex 429 & $3-17-86$ & $32,194 a$ & $241,753 a$ & $134 \mathrm{a}$ & 8.28 & 2.09 \\
\hline Texas Grano 502 & $3-17-86$ & $29,367 \mathrm{ab}$ & $217,843 a$ & $135 a$ & 8.12 & 2.00 \\
\hline 'Texas Grano 1025 Y & $4-04-86$ & $24,926 \mathrm{bc}$ & $238,266 a$ & $104 a b c$ & 8.11 & 2.09 \\
\hline Texas Grano 1105 Y & $4-04-86$ & $22,107 \mathrm{c}$ & $235,775 a$ & $95 \mathrm{bc}$ & 7.57 & 2.10 \\
\hline FMC-225 & $3-25-86$ & $21,625 c$ & $181,647 \mathrm{ab}$ & $125 \mathrm{ab}$ & 8.05 & 2.07 \\
\hline Texas Grano 1030 Y & $4-04-86$ & $21,009 c$ & $250,221 a$ & $85 \mathrm{c}$ & 8.67 & 2.10 \\
\hline Texas Early Grano 502 & $3-25-86$ & $20,842 \mathrm{c}$ & $194,598 \mathrm{ab}$ & $110 \mathrm{abc}$ & 8.21 & 2.11 \\
\hline Texas Grano $1015 \mathrm{Y}$ & $4-04-86$ & $15,252 d$ & $139,805 \mathrm{~b}$ & $113 a b c$ & 8.22 & 2.04 \\
\hline
\end{tabular}

'Planting date: 21 November 1985.

'Values in columns followed by one or more letters in common do not differ at the $\mathrm{P}=.05$ level using Duncan's Multiple Range test. 







\section{LITERATURE CITED}

1. Departamento de Agricultura. Anuario de Estadísticas Agricolas, 198i-86: 47-50, 8182.

2. Estación Experimental Agrícola, 1979. Conjunto Tecnológico para la Producción de Hortalizas. Esta. Exp. Agric. Univ. P. R. Publ. 102.

3. Estación Experimental Agrícola, 1984. Plaguicidas con permiso de uso en hortalizas. Esta. Exp. Agric. Univ. P. R. vol. V.

4. External Trade Statistics of P. R., 1986. Area of economics and social planning, Santurcee, $P$. R., pages 5 and 57 .

5. Lorenz, O. A. and D. N. Maynard, 1980. Knott's Handbook for Vegetable Growers. John Wiley and Sons. 2nd ed. pp. 33, 295, 314.

6. Mangual-Crespo, G. and E. Orengo Santiago, 1981. Yield and total solids content of four onion Allium cepa cultivars in southern Puerto Rico, J. Agric. Univ. P. R. 65 (4): $380-84$.

7. Pike, L. M., R. S. Hom and C. R. Anderson, 1988. Texas Grano 1030 Y: A late maturity, mild pungency short day onion. HortScience 23 (3): 636-37.

8. - R. S. Horn and C. R. Anderson, 1988. Texas Grano 1105 Y: A late maturing, medium length storage short day onion: HortScience 23 (3): 638-39. 